\title{
Erratum zu: Der HUS-Ausbruch 2011 in Deutschland. Herausforderung für den Infektionsschutz: Was sollte verbessert werden?
}

\author{
Bundesgesundheitsbl, Gesundheitsforsch, Gesundheits- \\ schutz (2013) 56:56-66 \\ http://dx.doi.org/10.1007/s00103-012-1585-1
}

In dem oben genannten Beitrag wurde in der deutschen und englischen Zusammenfassung sowie in der Einleitung eine falsche Jahreszahl genannt.

In der deutschen Zusammenfassung heißt der erste Satz richtig:

„Von Mai bis Juli 2011 ereignete sich in Norddeutschland der weltweit bisher größte Ausbruch von Erkrankungen am hämolytisch-urämischen Syndrom (HUS) mit schweren Folgen für die unmittelbar Betroffenen, das Gesundheitssystem und die Lebensmittelindustrie.“

In der englischen Zusammenfassung (Abstract) heißt der erste Satz richtig: „From May to July 2011 the world's largest outbreak of hemolytic uremic syndrome (HUS) occurred in northern Germany with dramatic consequences for the population, the health care system and the food industry."
In der Einleitung heißt der erste Satz richtig:

„Von Mai bis Juli 2011 ereignete sich in Norddeutschland der weltweit bisher größte Ausbruch von Erkrankungen am hämolytisch-urämischen Syndrom (HUS), der auch im Rückblick eine Bedrohung der öffentlichen Gesundheit war:"

Wir bitten, den Fehler zu entschuldigen. Die Redaktion

\section{Korrespondenzadresse}

Prof. Dr. G. Krause

Robert Koch-Institut

DGZ-Ring 1,

13086 Berlin

KrauseG@rki.de 